\title{
FENOMENA BEGU GANJANG DAN TANTANGAN PASTORALNYA ${ }^{1}$
}

\author{
Raja Oloan Tumanggor \\ Fakultas Psikologi Universitas Tarumanagara \\ rajat@fpsi.untar.ac.id
}

\begin{abstract}
Abstrak
Fenomena Begu Ganjang sempat menjadi masalah sosial di beberapa tempat di Sumatera Utara. Begu ganjang adalah sebutan tradisional untuk sejenis roh yang dapat menimbulkan mala pelataka bagi orang lain. Persoalannya adalah orang kerap menuduh orang lain memelihara begu ganjang, sehingga mendapat legitimasi dari masyarakat untuk membinasakan orang tersebut. Namun persoalan ini sebenarnya tidak lepas dari konsep masyarakat setempat mengenai roh yang diwarisi dari agama tradisional. Persoalan menjadi rumit karena ada sekelompok masyarakat mendapat stigma negatif pemelihara begu ganjang. Hal ini menjadi tantangan pastoral (kegembalaan) bagi pemimpin agama untuk mengatasi persoalan ini. Maka penjelasan tentang konsep begu ganjang yang tepat secara antropologis, teologis perlu disampaikan dan pendampingan rohani terhadap korban merupakan solusi yang bisa dilakukan.
\end{abstract}

Kata-kata kunci: begu ganjang, pastoral, fenomena, roh

\section{Pendahuluan}

Belakangan ini berkembang isu begu ganjang di Sumatera Utara, dan orang yang disangka memiliki begu ganjang diusir dari desa, malahan ada yang sampai dibunuh dan rumahnya dibakar. Fenomena tersebut membuat orang bertanya apakah begu ganjang, darimanakah asalusul dan makna kata tersebut. Selain itu gejala ini menjadi tantangan serius bagi kehadiran kekristenan dalam karya pastoralnya di tengah-tengah jemaat.

Paparan ini bukan bermaksud menjawab segala persoalan yang muncul sehubungan dengan begu ganjang, tapi hanya sebatas memberikan sedikit pemahaman terminologis dan sikap pastoral apa yang bisa dilakukan berhadapan dengan isu begu ganjang.

Secara sederhana dan harafiah begu sebetulnya berarti roh, sedangkan ganjang artinya panjang. Untuk memahaminya, begu ganjang mesti dilihat dalam konteks yang lebih luas dari 'teologi' dan 'agama' tradisional suku Batak Toba sendiri, secara khusus paham 'pneumatologi' Batak Toba $($ pneuma $=$ roh, spirit). Dari sudut pandang ilmu agama-agama dapat dikatakan bahwa

${ }^{1}$ Artikel ini sudah dimuat di Majalah Mingguan HIDUP edisi no 36, 7 September 2008, h. 8-9. Daftar Pustaka ditambahkan kemudian sebagai bahan referensi. 
dalam diri orang Batak Toba kuno telah terdapat konsep tentang keagamaan, yang walaupun orang Batak Toba kuno sendiri belum menyadarinya sebagai manifestasi keagamaan.

Masyarakat Batak Toba kuno telah berhasil mengembangkan suatu bentuk keagamaan primitif dengan menampilkan tokoh keallahan, diantaranya Mulajadi Nabolon sebagai Allah yang menciptakan segala sesuatu termasuk manusia, Debata Natolu yang terdiri dari Bataraguru, Soripada, dan Mangalabulan, dan terakhir adalah Debata Asiasi sebagai lambang kesatuan serta totalitas.

\section{Zat kehidupan}

Selanjutnya, masyarakat Batak Toba kuno percaya, disamping para Debata masih ada kekuatan lain yang erat hubungannya dengan kehidupan manusia. Malah baik buruknya hidup manusia tergantung pada respon yang diberikan pada kekuatan dan tenaga ini. Mereka itulah yang disebut dengan tondi dan begu.

Tondi (roh, nyawa) berada dalam tubuh manusia dan merupakan satu kesatuan. Manusia menjadi makhluk yang hidup karena memiliki tondi. Tondi memiliki zat kehidupan yang berlangsung selama-lamanya dan tidak dapat dirusak oleh apapun. Orang Batak Toba kuno mengenal dua jenis tondi, yaitu: tondi yang terdapat dalam tubuh manusia dan berhubungan dengannya pada masa kehidupan manusia saja. Kedua, tondi yang merupakan bayangan yang melanjutkan aktivitas manusia. Artinya, manusia secara biologis mungkin telah mati, tapi aktivitasnya masih dilanjutkan oleh tondi-nya.

Kehadiran tondi dalam tubuh manusia merupakan faktor penentu bagi kesehatan manusia. Timbulnya sesuatu penyakit, kegelisahan, atau kemalangan diyakini sebagai akibat dari lemahnya tondi, atau kepergian tondi dari tubuh manusia. Bila kepergian tondi berlangsung lama dan tidak datang lagi ke dalam tubuh dikhawatirkan bisa menyebabkan kematian bagi manusia. Konon ada empat penyebab tondi meninggalkan tubuh manusia yaitu saat tidur, terkejut, mimpi dan kematian (R. Pasaribu, 1988:130-131). 


\section{Rasa takut}

Apabila orang meninggal dunia, maka tondi berobah menjadi begu (Ph.L.Tobing, 1956:101). Jadi roh-roh yang menjadi begu inilah yang menimbulkan rasa takut bagi manusia yang masih hidup. Adanya rasa takut menjadi faktor utama aktivitas orang Batak Toba kuno untuk mengkultuskannya. Ini pula menjadi dasar ritus (kebaktian), yaitu upaya menghormati dan memuja begu sesuai keyakinannya (R.Pasaribu, 1988:125).

Pada umumnya begu dibagi dua golongan, yaitu (1) begu dari orang yang sudah meninggal, dan (2) begu lain yang berkeliaran di alam semesta yang secara umum dalam bahasa sehari-hari biasa disebut hantu (Parkin, 1978:148). Menurut sifatnya ada begu yang jahat dan begu yang baik (Marbun-Harahap, 1987:30). Sebenarnya orang Batak Toba kuno tidak menyebut begu kepada arwah orang yang dihormatinya. Arwah orang yang dicintai dan dihormati biasa disebut dengan sumangot (roh yang dipuja) dan sombaon (roh yang disembah).

Sehubungan dengan itulah ada ritus pemujaan nenek moyang berupa penggalian tulang belulang dari kuburan sementara (mangongkal holi) dan pemakaman kembali yang dilakukan bagi leluhur yang dianggap memiliki pengaruh istimewa. Melalui penghormatan, misalnya, dalam upacara adat diharap, bahwa roh nenek moyang akan diangkat menjadi sumangot. Bila dilakukan penghormatan lebih besar lagi bagi sumangot dan keturunannya menjadi kelompok besar, maka sumangot menjadi sombaon. Sombaon dipandang sebagai roh yang berkuasa dan harus dihormati, malah dipercaya dekat dengan para Debata yang menguasai kehidupan manusia.

Ada bermacam ragam sebutan untuk arwah orang mati yang dinamai begu, antara lain adalah begu laos bagi arwah orang yang semasa hidupnya merupakan pengemis, begu gunung untuk arwah orang yang sewaktu hidup bekerja sebagai pandai besi, konon arwahnya ditempatkan oleh Mulajadi Nabolon di puncak gunung. Begu jau adalah arwah orang yang tidak dikenal, begu nurnur bagi arwah orang yang mati tapi tempatnya belum sempat diukur sewaktu dimakamkan, begu siharhar untuk orang yang mati dengan tidak meninggalkan keturunan. Sementara begu antuk (roh pemukul) dan begu ganjang adalah sebutan bagi begu yang dapat memukul orang dengan tiba-tiba hingga menemui ajalnya. Kedua jenis begu ini dianggap banyak menyebarkan penyakit menular seperti kolera, sampar dan sebagainya. 
Demikian ulasan singkat mengenai paham orang Batak Toba kuno tentang begu dalam koteks 'pneumatologi' Batak Toba tradisional. Sehubungan dengan begu ganjang yang diyakini sebagai personifikasi bagi segala jenis roh-roh yang mampu membuat orang meninggal secara mendadak, segera muncul pertanyaan berikut: Adakah gejala dan isu begu ganjang yang sempat hangat di Sumatera Utara sebetulnya hanya merupakan gejala menularnya berbagai jenis penyakit membahayakan yang tentu saja dapat merenggut nyawa manusia dalam waktu singkat? Kalau memang itu, cara mengatasinya adalah menggalakkan pengobatan secara medis, bukan dengan menuduh dan membinasakan orang yang diduga memiliki dan memelihara begu ganjang.

\section{Pendampingan pastoral?}

Oleh karena itu, dalam menghadapi masyarakat atau umat yang menyebarluaskan isu begu ganjang sebetulnya dibutuhkan pendekatan pastoral yang bijaksana.

Terlepas dari persoalan apakah memang begu ganjang ada atau tidak, menarik untuk mengamati mengapa masyarakat menghembuskan isu begu ganjang tersebut. Berbagai faktor, misalnya, kecemburuan sosial, persoalan ekonomi, dan persaingan politis bisa mendasari orang memunculkan isu begu ganjang. Kegersangan dan kehampaan iman kristiani serta kebuntuan dalam menghadapi segala jenis persoalan kehidupan sehari-hari juga dapat merangsang orang untuk cepat melemparkan tanggungjawab dan kesalahan kepada pihak lain. Dengan meminjam terminologi begu ganjang orang merasa lebih gampang menghakimi pihak lawan atau orang lain yang tidak disenangi sebagai pihak yang bersalah, sumber permasalahan, dan penderitaan, maka harus segera dibinasakan.

Berhadapan dengan gejala ini beberapa kebijakan pastoral yang barangkali bisa dilakukan adalah: Pertama, memberikan penjelasan yang benar secara antropologis, historis dan sosiologis kepada jemaat seputar begu ganjang, sehingga orang mengerti latar belakang kemunculan kata begu ganjang pada masyarakat. Kedua, menggalakkan diskusi dan seminar secara teratur mengenai isu yang hangat di masyarakat, sehingga umat merasa terlibat dan turut memikirkan pemecahan atas persoalan yang muncul di antara mereka. Ketiga, mengadakan pendekatan dan 
pendampingan pastoral kepada kedua belah pihak baik korban atau pihak yang dituduh memelihara begu ganjang, maupun kelompok masyarakat yang yang sudah dan/atau potensial bertindak anarkis.

\section{Daftar Pustaka}

Marbun, M.A.; Harahap, I.M.T. (1987). Kamus Budaya Batak, Balai Pustaka.

Parkin, Harry (1978). Batak fruit of Hindu Thought, Madras, Christian Literature Society.

Pasaribu, Rudolf (1988). Agama Suku dan Batakologi, Penerbit Pieter, Medan.

Tobing, Ph. L. (1956). The structure of the Toba-Batak belief in the high God. Amsterdam (Jacob van Campen), (Diss. Utrecht). 